\title{
The Russian Revolution of 1917 and the Kremlin's Policy of Remembrance
}

Jens Petter Nielsen (UiT The Arctic University of Norway)

7 he first time I visited the Lenin Mausoleum was on an autumn day in was lying in dim illumination, immaculately dressed in a dark suit, white shirt, and a red necktie. Despite his attire, he made a dismal impression with his yellow, parchment-like skin. Twenty years later, Soviet society dissolved, without Lenin being offered a decent burial. He is still there, in Red Square, and when I visited the Mausoleum once more in 2016, his suit was still black but the necktie had been swapped for a blue one. Lenin, without doubt, looked better than he had done forty-five years earlier. When I came out again into the daylight, one question presented itself: why is it that Russians continue to honor the memory of the founder of the Soviet state and architect of the October Revolution, when we know that Russia today has a political regime that is based on a repudiation of Communism? Why is Lenin still lying in state, guarded by some of Russia's finest soldiers?

This is the question that will be addressed here: what kind of perception of history, or rather remembrance policy, underlies the Kremlin leadership's management of Lenin's embalmed body and the entire history of the Russian Revolution? In a recent article S. A. Smith, a leading British specialist in Russian and Chinese history, states that "[o] ur ability to understandcertainly to empathize with-the aspirations of 1917 has diminished." Less research is being done on the Russian Revolution, according to Smith, owing to the advance of neoliberalism and the marginalization of the Left in Western countries. Neither the so-called color revolutions in the Ukraine, in Georgia, and in Kyrgyzstan, nor the Arab Spring have fulfilled the expectations that they raised in the beginning. With few exceptions, they have

1 S. A. Smith, "The Historiography of the Russian Revolution 100 Years On," Kritika: Exploration in Russian and Eurasian History, 16 (2015): 733. 
become examples of how difficult it is to achieve political progress through violent means. ${ }^{2}$ We should add that the color revolutions in the post-Soviet space have created fear of a new revolution in Russia, and this undoubtedly forms part of the backdrop for the Putin administration's remembrance policy with regard to the revolution.

Since Stalin's time (without making invidious comparisons), no Russian leader has been more preoccupied with the past than Vladimir Vladimirovich Putin. In the 1930s, there was no open debate on Russia's history and, in particular, on the history of the Russian Revolution. To take a false step in this field was no joking matter, and historians lived in fear and trepidation. Stalin's intervention in the historical field was a kind of remembrance policy, even if this concept had not yet been formulated. Remembrance history comprises not only the writing of history, but "the whole sphere of public strategies with regard to the past, the entirety of different practices and norms, connected with the regulation of the collective remembrance." ${ }^{3}$ Hereto belong measures for erecting memorials, producing historical exhibitions in museums, marking by celebration of particularly significant events in the past, and directing attention to some topics in the past while being silent about others. Remembrance policy can be exerted not only by the state, but also by other agents, while the concept "history policy," as used by A. I. Miller, presupposes "the use of state administrative and financial resources in the sphere of history and policy of remembrance in the interests of the ruling elite." 4

Even if the Kremlin leadership today has a guiding hand when it comes to the political use of history in Russia, it can be said without irony that, compared with Stalin, Putin handles historians with kid gloves. By and large, he leaves the historical debate in Russia open. It is true, however, that the Kremlin interferes in the financing and organization of historical research, the writing of textbooks, erection of monuments, media reach, etc. In this way, it makes sure that the official discourse on national history

2 Smith, "The Historiography of the Russian Revolution," 733.

3 Remembrance history as defined by D. V. Efremenko at a seminar organized by the Institute of Scientific Information of Social Sciences (INION), Russian Academy of Sciences, Moscow, on October 12, 2017, under the heading "Stoletnii iubilei revoliutsii 1917 goda i rossiiskaia politika pamiati: Kommemoratsii stoletiia revoliutsii v Rossii: ot pamiati k politikam pamiati," November 7, 2017, accessed May 26, 2018, http://gefter.ru/archive/23171.

4 A. I. Miller, "Istoricheskaia politika v Vostochnoi Evrope nachala XXI veka," in Istoricheskaia politika $v$ XXI veke, ed. A. Miller and M. Lipman (Moscow: Novoe literaturnoe obozrenie, 2012), 19. 
gets a lot of attention, and there is reason to believe that this pressure from above will increasingly impact professional historians' interpretations in the years to come. ${ }^{5}$

In spite of fundamental disparities, we still find some common features in Stalin's and Putin's way of arguing: in the 1930s Stalin called the historian Mikhail Nikolaevich Pokrovskii (1868-1932) and his so-called school to account for their way of writing history. Pokrovskii was the leader of the first Marxist generation of Soviet historians that had dominated the field in the 1920s. One of their main concerns was to justify the October Revolution, and for that reason they painted Russia's history before 1917 in bleak colors, seeing continuity between a dark past and a bright future. The party leadership was not satisfied with Pokrovskii's disciples, because they reduced Russian history to a series of socioeconomic formations, with no place for individual destinies - and without national glory. ${ }^{6}$ During the phase of intensive socialist construction in the 1930s, a cultural readjustment to prerevolutionary national values took place in the Soviet Union. ${ }^{7}$ Soviet youth should be given reasons for being proud of their own country's history; it was no longer appropriate to represent the Russian tsars as little more than bloody oppressors. Some of them were great commanders who had defended Russia against foreign intruders, consolidated the Russian state, and made it a great power.

The core of Putin's history policy is, likewise, to strengthen Russian national values. As he told the Russian Federal Assembly in 2012, "Precisely in civic responsibility, in patriotism I see the consolidating basis of our policy." ${ }^{8}$ When in the beginning of the 2000s he started to take interest in history in earnest, Putin pointed to the fact that in the 1990s, the beginning of the post-Soviet period, Russian historians "had underlined the negative, because the task was to

5 See B. I. Kolonitskii, "On Studying the 1917 Revolution: Autobiographical Confessions and Historiographical Predictions," Kritika: Exploration in Russian and Eurasian History 16 (2015): 751-768.

6 See Konstantin F. Shteppa, Russian Historians and the Soviet State (New Brunswick, NJ: Rutgers University Press, 1962), 102-108; George M. Enteen, The Soviet Scholar-bureaucrat: M. N. Pokrovskii and the Society of Marxist Historians (University Park, PA: The Pennsylvania State University Press, 1978), 193-199.

7 See Nicholas Timasheff, The Great Retreat: The Growth and Decline of Communism in Russia (New York: D. P. Dutton, 1946).

8 “Poslanie Prezidenta Federal'nomu Sobraniiu," February 12, 2012, accessed May 26, 2018, http://www.kremlin.ru/news/17118 and http://www.kremlin.ru/events/president/transcripts/15781. 
destroy the old system," that is, the Soviet system. Now, however, one faced not a destructive but "a constructive task" - to build the new Russia.

Putin wanted to root his new regime in history and the national community after the troubles and degradations of the 1990s, and at the same time make sure that no groups ended up outside this community. Putin was engaged in creating a "United Russia" (Edinaia Rossiia), which also became the name of his political party. However, unlike Stalin, who intervened in the historical field on behalf of the victors in the Russian Revolution and Russian Civil War, Putin is searching for a conciliatory narrative of the kind which, according to Aleida Assmann, rightly should be offered to both victors and losers, allowing them "to include one's conflicting views on the events into a common context on a higher level." 10

Among professional historians in post-Soviet Russia the view of the revolution has changed much more than in the West, and many historians of the Soviet school who used their younger days to study and endorse the October Revolution have now distanced themselves from it. During the Soviet period, research on the Russian Revolution was a highly prioritized, but at the same time strictly regulated, field that affected the very legitimacy of the Soviet order. The Great October Socialist Revolution was the foundation myth of the Soviet state, and it became the start of Russia's triumphant motion from capitalism towards socialism, an heroic event that all of a sudden placed one of Europe's most backward countries at the very head of social progress worldwide. ${ }^{11}$

It is not difficult to understand that after the breakdown of the Soviet Union the new, post-Soviet leadership in Russia needed a reinterpretation of the Russian Revolution and a new scheme that would explain the connection between the past and the present of the country after the rejection of historical materialism. Eltsin did not get very far in creating a new general reinterpretation or "metanarrative" of Russian history. In the 1990s, criticism of the Soviet order was the main instrument in legitimizing the ongoing reforms, and Eltsin's

9 N. Sokolov, "Vek surka, ili Kratkaia istoriia kolovrashcheniia rossiiskikh uchebnikov istorii," Polit.ru, October 15,2008, accessed October 18,2016, www.polit.ru/analytics/2008/10/15/ history.html.

10 Aleida Assmann, Der lange Schatten der Vergangenheit: Erinnerungskultur und Geschichtspolitik (München: Beck, 2006), 71.

11 Sheila Fitzpatrick, "Celebrating (or Not) the Russian Revolution," Journal of Contemporary History 52 (2017), 817. 
regime very quickly started to identify itself with the values that had earlier, during the Cold War, been ascribed to the capitalist West. ${ }^{12}$

It was more difficult for Russia than for the other post-Soviet states to stake a lot on national values, due to the multinational nature of the Russian Federation. Neither could Eltsin, just like that, choose the imperial or great power paradigm, since he himself had worked so determinedly for the dissolution of the Soviet Union. Therefore, the new post-Soviet Russian identity had to be built mainly on the contrast with the totalitarian past and the new "democratic," Western values. ${ }^{13}$ The emphasis was clearly on the breach, rather than the continuity, with earlier epochs in Russian history. A change was discernible, however, from the second half of the 1990s, after the 1996 elections, which became a success for the Communist Party of the Russian Federation and its leader, G. A. Ziuganov. Instead of a fundamental dissociation from the Soviet heritage, came a new emphasis on reconciliation in Eltsin's history policy, and November 7, the Revolution Day, was renamed "The Day for Reconciliation and Accord." 14

Another visible effect of this was the conspicuous official reburial of the mortal remains of the last tsar family and his family. However, Eltsin and his acolytes were presumably still under the spell of the Soviet narrative of prerevolutionary Russia, perceiving the authoritarian ancien régime as a contrast to "democratic" Russia. It was essential to uphold this divergence in order to emphasize the enormity of ongoing reforms. ${ }^{15}$ Anyhow, Eltsin lacked a plausible narrative that in a positive way could connect the present with the imperial period of Russian history.

Ever since he took over as president of the Russian Federation in 2000, Putin has been even more dedicated to reconciliation with the Soviet past. At first, he was influenced by what Olga Malinova calls the "popular-patriotic opposition," in particular the Communist Party of the Russian Federation and its interpretation of Russia's history, which, unsurprisingly, is more open to the positive values in the Soviet epoch. At the beginning of his first presidential term, Putin characteristically persuaded the State Duma to vote for the retention of several Soviet state symbols, among them the red flag and Soviet star for the Russian armed forces, as well as the old Soviet anthem, albeit with a new

12 See R. W. Davies, Soviet History in the Yeltsin Era (London: Macmillan Press, 1997).

13 See Olga Iu. Malinova, Aktual'noe proshloe: Simvolicheskaia politika vlastvuiushchei elity $i$ dilemmy rossiiskoi identichnosti (Moscow: ROSSPEN, 2015), 175-178.

14 Malinova, Aktual'noe proshloe, 179-180.

15 Olga Iu. Malinova, "Neudobnyi iubilei: itogi pereosmysleniia 'Mifa osnovaniia' SSSR v ofitsial'nom istoricheskom narrative RF," Political Science (RU) 3 (2017): 22-24. 
text. ${ }^{16}$ And since then Putin has stuck to this conciliatory strategy. His message to the Federation Council in 2016 was that

the lessons of history we need first and foremost in order to strengthen the societal, civic agreement that we have succeeded in obtaining. ... It is inadmissible to drag schisms, malice, offences and bitterness of the past into our present [social] life, in one's own political and other interests to speculate in tragedies, which touched upon practically every family in Russia, regardless of on which side of the barricades our ancestors ended up. Let us always remember: we are a united people, we are one people, and Russia is one and the same for us [Rossiia $u$ nas odna.${ }^{17}$

Thus the Kremlin leadership is still careful not to alienate those Russians who are nostalgic about the Soviet period and its lost stability, especially elderly people. And they are still numerous. This was possibly the main reason why Putin and his collaborators were deliberately ambiguous in their statements in connection with the centenary of the revolution in 2017. For the commemoration of 1917 was not only about the revolution, something that happened a hundred years ago. It was about a whole epoch in Russian history, which was introduced by the revolution. So, according to Russian Minister of Culture Vladimir Medinskii, one should avoid dividing people into the just and the unjust, into Reds and Whites, and instead realize that both groups who fought in the revolution and civil war, were guided by patriotic feelings and a wish to defend Russia. They simply understood the task differently. ${ }^{18}$ This ambiguity on the part of the Kremlin leadership is the reason why Lenin, the founder of the Soviet state, is still on display on Red Square. Putin does not want to have him removed before an overwhelming majority of the Russian population is in favor of expelling him from the Mausoleum. ${ }^{19}$ That would upset the older generation, since it would imply that millions of Soviet citizens had nourished

16 See Kristian Lundby Gjerde, "The Use of History in Russia 2000-2011: The Kremlin and the Search for Consensus," East European Politics 31, no. 2 (2015): 152.

17 "Poslanie Prezidenta Federal'nomu Sobraniiu," December 1, 2016, accessed March 25, 2018, http://www.kremlin.ru/events/president/news/53379.

18 "Navstrechu 100-letiiu Revoliutsii: Zveno v istoricheskoi preemstvennosti i platforma primireniia," May 20, 2015, accessed May 26, 2018, http://www.odnako.org/blogs/ navstrechu-100-letiyu-revolyucii-zveno-v-istoricheskoy-preemstvennosti-epoha-gigantskih-dostizheniy-i-platforma/. See also Fitzpatrick, "Celebrating (or Not) the Russian Revolution," 827.

19 See the newspaper Argumenty ifakty, May 7, 2009. 
false ideals during the seventy-four years of Soviet power. To reach this end, the removal of Lenin, we will probably have to wait until the generations that learned to look up to him are gone. But as long as Lenin is on Red Square, says the Russian historian Edvard Radzinskii, "the Revolution continues."20

Post-Soviet Russia needs not only reconciliation. Another main concern is to give the country a firmer historical identity, and this goal seems to be incompatible with reconciling the Reds and the Whites with each other. Putin and his closest staff members in the field of history, such as Sergei Naryshkin - the present head of Russia's Foreign Intelligence Service and chairman of the Russian Historical Society-and Minister of Culture Medinskii, agree that the only thing that can give Russian history a firm coherence after Marxism-Leninism is Russia's great power tradition, which ascribes to the Russian state a unique and beneficial role in forging Russian society through the ages. All this seems to be in accordance with well-known postulates of the prerevolutionary Russian state historical school. ${ }^{21}$

Through their textbook projects and erection of monuments and memorials, like the huge statue of Saint Vladimir just outside the Kremlin, the statue of Tsar Alexander III in Crimea, the memorial devoted to Russian soldiers who were killed on the battlefield during the Great War and so on, the Kremlin leadership has been preoccupied with constructing an "infrastructure of remembrance" of key events and heroes, a symbolic axis that links post-Soviet Russia firmly with both the Soviet and the prerevolutionary tsarist past. This axis is Russia's great power status, irrespective of the regime, and a key concept in this connection is preemstvennost' (continuity), ${ }^{22}$ which is projected on the whole "millennial history" of Russia.

A major problem for this new metanarrative of Russian history is how to make the Russian Revolution fit into the scheme. One crucial issue in this connection is the correlation between the revolution of 1917 and the First

20 Elena Novoselova, "Poka Lenin na Krasnoi ploshchadi, revoliutsiia prodolzhaetsia," Rossiiskaia gazeta, November 17, 2015, accessed January 6, 2017, https:// rg.ru/2015/11/18/radzinskiy.html.

21 These postulates are neatly summarized in Pavel N. Miliukov, Ocherki po istorii russkoi kultury, vol. 1 (St. Petersburg: Tipografiia M. A. Aleksandrova, 1904). Miliukov, one of Russia’s foremost historians, believed that the state paradigm was the key to understanding Russia's past. As a liberal politician and leader of the Constitutional Democratic Party, however, he went in for changing Russia's course in the direction of liberal democracy and the parliamentary system. To obtain this, it was crucial to get away from the "millennial" hypertrophic state.

22 See Malinova, Aktual'noe proshloe, 180. 
World War. Among Western historians it has always been a conviction that the Russian Revolution grew out of the war. And that still seems to be the case. Joshua A. Sanborn, for instance, maintains that "the Russian Revolution as a whole was a product of the war and was decisively influenced by soldiers at every key stage." ${ }^{23}$ Christopher Read likewise writes that without August, 1914, "the revolution as we know it could not have taken place." ${ }^{24}$ In a recent article, Rex Wade states that what no historian today disagrees with "is that the war doomed the regime of Nicholas II." ${ }^{25}$ Comparative research on revolutions also indicates that great revolutionary upheavals generally only succeed if the old regime is weakened in advance because of external strains. ${ }^{26} \mathrm{~S}$. A. Smith in his new book on the Russian Revolution reminds us of the fact that in practically all socialist revolutions in the twentieth century, it was imperialist wars that led the old regimes into crisis. ${ }^{27}$

Military defeat, war weariness, and lack of food and coal for heating in the cities were important reasons for the fall of tsardom and also for the problems of the so-called Provisional Government, which only existed for eight months. Contrariwise, the war explains a great deal of the Bolshevik success in the autumn of 1917, even if the general deterioration in living conditions for the working class in Petrograd may have been more important than the desire for peace. ${ }^{28}$ Today the majority of historians, both in the West and in the East, find it difficult to imagine the Russian Revolution of 1917 without the three years of preceding war. The War that Gave Birth to a Revolution is the title of V. P. Buldakov and T. G. Leont'eva's 2015 book on the First World War. ${ }^{29}$

In the Soviet era, however, it was not acceptable to use the Great War as an explanation for why a successful revolution occurred in Russia, because that would call into question the legitimacy of October, 1917, as revolution in a

23 Joshua A. Sanborn, Imperial Apocalypse: The Great War and the Destruction of the Russian Empire (Oxford: Oxford University Press, 2014), 235.

24 Christopher Read, War and Revolution in Russia, 1914-1922 (Basingstoke: Palgrave Macmillan, 2013), 22.

25 Rex Wade, "The Great War, Revolution and the Struggle Over Peace: Russia 1917," Revolutionary Russia 30, no. 2 (2017): 182.

26 See Theda Skocpol, States and Social Revolutions: A Comparative Analysis of France, Russia and China (Cambridge: Cambridge University Press, 1979).

27 S. A. Smith, Russia in Revolution: An Empire in Crisis, 1890 to 1928 (Oxford: Oxford University Press, 2017), 4.

28 Smith, Russia in Revolution, 119-120. On the other hand, one can, of course, surmise that the worsened living conditions to a large extent resulted from the war.

29 V. P. Buldakov and T. G. Leont'eva, Voina, porodivshaia revoliutsiiu: Rossiia, 1914-1917 gg. (Moskva: Novyi khronograf, 2015). 
Marxist sense. Especially from the 1930s it was important to show that the October Revolution was caused by classical Marxist prerequisites for a socialist workers' revolution and that it was deeply rooted in Russian society itself. It was wrong to attach too much importance to external impulses, even if Lenin himself saw a clear connection between the Great War and the revolution.

Remarkably enough, as long as the Soviet Union existed, not a single memorial was erected to honor the Russian soldiers that fell on the battlefield in the years 1914-1917. Altogether, 1.7 million soldiers perished. No anniversaries were marked in connection with the First World War. Why? The explanation is that the October Revolution was programmatically an anti-national revolution and a revolt against the war. Lenin wanted to transform the Great War from being a war between nations to becoming a war between classes. And he succeeded-but only in Russia.

The negative view of Russia's participation in the First World War was so entrenched in the minds of the Russians that it was some twenty years after the dissolution of the Soviet Union before they were ready to do anything about it. Only in 2010 did the Kremlin leadership decide to rehabilitate the First World War as a symbol for Russian heroism and suffering. In his speech to the Russian Federal Assembly on June 27, 2012, Putin declared that Russia's defeat in the First World War resulted from the treachery of the Bolshevik leaders: he blamed them for having withdrawn Russia from the war and signed a disgraceful peace with the Central Powers, the Brest-Litovsk peace treaty on March 3, 1918, when Russia finally withdrew from the war:

Our country lost this war to the loser. A unique situation in the history of mankind! We lost to Germany, which was already on the losing side. In reality we capitulated to her, and she after some time capitulated to the Entente. And this was the result of a national betrayal of the leadership of the country at that time. ${ }^{30}$

The Bolsheviks had to accept the independence of Poland, Finland, the Baltic states, and Ukraine (in practice, Ukraine became a German protectorate), also ceding parts of the Caucasus. Later, they would not acknowledge that BrestLitovsk was a mistake, said Putin, and therefore they continued to name this war "imperialist" and failed to honor the Russian army and its heroism.

30 “Poslanie Prezidenta Federal'nomu Sobraniiu," February 12, 2012, accessed May 27, 2018, http://www.kremlin.ru/news/17118 and http://www.kremlin.ru/events/president/transcripts/15781. 
On August 1, 2014, Putin unveiled the first official Russian monument in the war memorial park Poklonnaia Gora in Moscow devoted to the Russian soldiers that died during the Great War. August 1, 1914, was the day when Russia joined the Allies, and it has become the official day of remembrance for this war in Russia. On account of the Bolsheviks, Russia became a victim in the war, instead of taking part in sharing the fruits of victory. ${ }^{31}$ This reevaluation of the Great War is also a suitable issue for bringing together two different RussiasRussia proper and Russia abroad (the latter comprised of those who fled the country because of the 1917 Revolution-or, today, their descendants.) ${ }^{32}$ At the initiative of Russian émigré groups and the Russian Ministry of Culture, a memorial will reportedly be raised in Crimea, where the civil war in the European part of Russia came to an end in November, 1920.

The idea of "the stolen victory" was an important element in the Kremlin leadership's history policy in the 2014 centenary year. The need to rehabilitate Russia's participation in the First World War is connected with the fact that The Great Patriotic War (1941-1945) has become even more important in post-Soviet Russia than it was before. It has been called the Putin regime's foundation myth, ${ }^{33}$ and has done a great deal to displace the memory of the revolution. ${ }^{34}$ Remembrance of the war, as it were, makes all dissonance die away. Ideological conflicts, contradictions between generations, as well as between ethnic groups, disappear like magic. Victory Day-May 9-is today perceived by most people as the country's real national day, and it is definitely about displacing the memory of the Russian Revolution and November 7.35

What the post-Soviet foundation myth really is about, however, is not the war itself, but the Putinist idea of the historical continuity of the Russian great power tradition, where the victory over Nazi Germany only represents the absolute apex. As a rule, foundation myths have a "before" and an "after"; but

31 This view is shared by quite a few professional Russian historians today, among them the well-known Boris N. Mironov (B. N. Mironov, personal communication, St. Petersburg, September 24, 2016).

32 Vera Tolz, "Modern Russian Memory of the Great War, 1914-1920," in The Empire and Nationalism at War, ed. E. Lohr, V. Tolz, A. Semyonov, and M. von Hagen (Bloomington: Slavica, 2014), 279.

33 See Nikolai Koposov, Pamiat' strogogo rezhima: Istoriia i politika v Rossii (Moscow: Novoe literaturnoe obozrenie, 2011), 163.

34 Jens Petter Nielsen, “'̊̊ skape mening i konsolideringens navn’: Den russiske revolusjonens hundreårsjubileum," Arbeiderhistorie (2017), 23-41.

35 Markku Kangaspuro, "History Politics and the Changing Meaning of Victory Day in Contemporary Russia," in The Long Aftermath: Cultural Legacies of Europe at War, 19362016, ed. Manuel Bragan and Peter Tame (Oxford: Berghahn Books, 2015), 333-343. 
in this case the emphasis is on continuity, or rather on a cyclical conception of history, where the principle on which the history of modern Russia is allegedly based, with certain intervals, reappears with a particular clarity. In this connection, the Great War is considered as a necessary stepping stone between imperial Russia, the Great Patriotic War and post-Soviet Russia, which is about to regain its great power status under the leadership of Vladimir Putin. ${ }^{36}$ Because one hundred years ago the October Revolution came about as an upheaval against the First World War, it ended up casting a shadow over Russia's participation in this war throughout the entire Soviet period. Now, when Russia's new leadership has decided that the First World War was also a war for Russia's honor and national interest, it has started to cast a shadow over the 1917 revolutions in both October and February.

When Boris Eltsin in 1998 renamed November 7 "The Day for Reconciliation and Accord," the intention was that this day, instead of being a day for commemorating the Russian Revolution, should be used for overcoming the split that the revolution created, which still persists between those who have positive feelings about the Soviet past and those who are against it. In 2005 Putin renamed "The Day for Reconciliation and Accord," calling it "The Day for National Unity," and moved it to November 4, a date that is historically related to the investiture of the Romanov dynasty in the early seventeenth century and the restoration of the Russian state after the Time of Troubles. This was a deliberate move to divert attention away from the discord about the Soviet past towards the heritage of Russian state building. Presumably it was no accident that this decision was taken on December 29, 2004, three days after the conclusion of the Ukrainian Orange Revolution. ${ }^{37}$

In this way the revolution was symbolically downgraded, and for many years Putin and Medvedev would not speak about the Russian Revolution unless they had to. Since the beginning of the new millennium, November 7 , the old Revolution Day has been swallowed up by historical military parades. On Revolution Day in 1941, when German military detachments were getting close to Moscow and could already glimpse the domes of the Kremlin, Stalin

36 For Boris Eltsin in the 1990s, the Great Patriotic War had first of all the merit of "the courage, patriotism and self-sacrifice" of the Soviet people, not of the Stalinist, totalitarian leadership (see Malinova, Aktual'noe proshloe, 91-100).

37 See Vladislav Inozemtsev, "Razdvoenie soznaniia," Nezavisimaia gazeta (Moscow), November 7, 2012, 2. Malinova suggests that Putin's personal views also played a part here; according to her, Putin has never been particularly fond of the October revolution (Malinova, Aktual'noe proshloe, 78-79). 
ordered a military parade on Red Square to demonstrate the Russians' indomitable readiness to fight. In recent years, on November 7, parades have been held on Red Square in imitation of the 1941 parade, including uniforms of the time and equipment from the Second World War. In this way, Revolution Day has changed its nature completely from being a day of remembrance of the October Revolution to becoming yet another day of remembrance of the victory over Nazi Germany.

The foundation myth of the Soviet state, however, cannot simply be pushed away, because of the dimension of this event-and its international repercussions; and the problem remains that the Russian Revolution unavoidably weakens the continuity of the Russian great power tradition. Seen from the Kremlin's point of view, the main problem with the Bolsheviks is perhaps not communism, but the fact that they tore down the old tsarist state and afterwards entered into a separate peace with Russia's enemies. Of course, it would have been possible for Putin to distance himself from October 1917 but embrace the February Revolution, which aimed at introducing democracy in Russia. But that was not the case either. In the year 2000, Putin became friends with Alexander Solzhenitsyn, the great writer and outspoken and intrepid Soviet dissident, who had returned to Russia in 1994 after twenty years' exile in the West. This was an unlikely alliance, of course, since Putin came from the KGB, an organization that Solzhenitsyn had spent his entire life combatting. Elena Bonner has called their friendship "a psychological problem worthy of Dostoevsky's pen." 38

The struggle against revolution had been a governing idea throughout Solzhenitsyn's public life, and Putin came to share his views on the February Revolution and its topicality. When in 2005 the Orange Revolution took place in Ukraine, Solzhenitsyn involuntarily compared it with the February Revolution in Russia in 1917. In those days, Germany was behind the scenes, helping Lenin and other Bolsheviks get back to Russia, supplying them with money, and so on. A hundred years later, Western philanthropic organizations played the same role, according to Solzhenitsyn, encouraging revolutionary unrest in Ukraine. February, 1917, brought mediocrities to power in Russia, maybe with the best of intentions, but they were spineless and soon swept away by Lenin and the Bolsheviks. ${ }^{39}$

38 R. Horvath, "Apologist or Putinist? Solzhenitsyn, the Oligarchs, and the Specter of Orange Revolution," The Russian Review 70, no. 2 (2011), 300-318.

39 Horvath, "Apologist or Putinist?", 311. 
Solzhenitsyn's views on the February Revolution touched deep-felt chords within the Kremlin leadership, ${ }^{40}$ and on March 13, 2007, the Kremlin organized a round table conference on Solzhenitsyn's article "Reflections on the February Revolution" 41 at the Russian State Humanistic University in Moscow. Here Vladislav Surkov, Putin's vice chief of staff and the theoretician behind the concept of "sovereign democracy," gave a programmatic speech entitled "A Resignation Speech of a Growing Liberal." It says a great deal about Solzhenitsyn's influence on Putin's inner circle. Surkov repeated the thesis that the liberal leaders who came to power in February, 1917, in practice prepared the soil for Bolshevism:

In my opinion, October had already taken place in February. At least it was predetermined and power did not belong, in my opinion, to the democratic public for a minute at that time. It is a fact that the real power, the revolutionary energy, the real political power was on the side of the most radical, the extremist groups... . Aleksandr Isaevich Solzhenitsyn calls on to protect the people, and we are happy to support this idea, and the president [V. V. Putin] has used this expression in one of his speeches. We have to remember that revolution, first and foremost, is a waste of human beings, it is first and foremost about destruction. ${ }^{42}$

It can be said that Putin's concern about not offending anybody works against the wish to create an inner coherence and continuity in history, because his strategy is oriented not towards mastering the past, but rather towards ignoring it. Yet even an outright condemnation of the idea of revolution (as above) does not fit into the great power scheme. Even if the Great War has been rehabilitated and cleared as a necessary stepping stone between the imperial period of Russian history and the Second World War, the foundation of the Soviet order, that is, the revolution, still has to be worked somehow into the new metanarrative of Russian history. It is significant that in 2017 the Kremlin did not find it suitable to erect any kind of memorials devoted to the revolution, and there was no official commemoration of the centenary of 1917 . The official response to this particular jubilee has clearly been "underwhelming."43

40 Nielsen, “Å skape mening i konsolideringens navn," 32-33.

41 Published for the first time in A. I. Solzhenitsyn, Publitsistika, vol. 1 (Iaroslavl': Verkhniaia Volga, 1995), 457-503, but written already in the 1980s.

42 Vremia novostei, 50, March 23, 2007.

43 Matthew Rendle and Aaron B. Retish, "Silences and Noises: Commemorating 1917," Revolutionary Russia 30, no. 2 (2017): 151. 
The whole question of the meaning and historical significance of the Russian Revolution was handed over to academia, which by and large was not ready to take part in the Kremlin's remembrance policy.

Putin was not completely silent about the revolution, though. In greetings to conferences in Moscow, St. Petersburg, and other places, he again urged Russians to use the centenary to put an end to the division that the revolution had created. Furthermore, he warned against the schisms that revolutions necessarily create. But what is more important, if not directly then indirectly, he condemned the Russian Revolution one week before November 7, 2017. In 1889, the French built the Eiffel tower to mark the centenary of the Great French Revolution; Putin marked the birthday of the Russian Revolution by opening the Pandora's box of Stalin's crimes. On October 30, he was present at the opening of an impressive memorial on the Sakharov prospect, devoted to the victims of political repressions in the USSR, the thirty-meter long Wall of Sorrow (Stena skorbi). He did not attempt to hide that, in his opinion, the opening of this memorial was particularly topical in the year of the centenary of the Russian Revolution. ${ }^{44}$ At the unveiling ceremony, he stated that "this terrible past is impossible to erase from the national remembrance and even more impossible to justify with any higher so-called common good of the people."45

Still, there is a problem with Putin's anti-revolutionary, anti-Bolshevik position. The issue is the nexus created between the Great War and the Great Patriotic War in the infrastructure of remembrance. Paradoxically, while it is easy to stigmatize the Bolsheviks as traitors in the First World War, when they tore down the old tsarist state, they are inextricably linked with the victories in the Second World War. Even if the Russian Revolution ruined the tsarist state, apparently it did not weaken Russian statehood in the long run. Quite on the contrary, the Bolsheviks, by industrializing the country and centralizing its political power structures, opened a new era of Russian state-building, which exceeded everything that Russia had achieved in the past. Without October, it is indeed doubtful that Russia could have done so well during the Second

44 "Putin prizval $\mathrm{v}$ god stoletiia revoliutsii podvesti chertu pod raskolom naroda," $R B C . r u$, accessed July 18, 2018, https://www.rbc.ru/politics/30/10/2017/59f723f89a794713e. October 30 is the official Day for commemorating the victims of political repressions in Russia.

45 "V Moskve otkryli memorial zhertvam repressii," Novaia gazeta, October 30, 2017, accessed May 9, 2018, https://www.novayagazeta.ru/news/2017/10/30/136550-v-moskve-otkryli-memorial-zhertvam-repressiy-na-tseremoniyu-otkrytiya-steny-skorbi-priehal-putin. See also James Ryan, “The Politics of National History: Russia's Ruling Elite and the Centenary of 1917," Revolutionary Russia, 31 (2018): 13-14. 
World War. This dilemma is difficult to resolve, and it manifests itself in Stalin's person and his dual role as Lenin's successor and Generalissimo during the Great Patriotic War.

Could it not have been different? Is it possible that October could be included in Putin's metanarrative of Russia's history? Putin did take a step further with his history policy when in 2007 he put forward a plan for a new series of textbooks on history for Russian schools. The first result of this was a new instruction book for history teachers, which turned out first and foremost as an account of Russia as a great power. ${ }^{46}$ As was to be expected, it underlines the continuity of Russia's state tradition, and its author, A. V. Filippov, went to considerable lengths to integrate the revolution into this narrative. In his scheme, not only the Great War but also the Russian Revolution becomes a necessary stepping stone onwards to today's post-Soviet Russia. To achieve this, Filippov even invoked the philosopher Nikolai Berdiaev (1874-1948), who considered Bolshevism a kind of modern "anti-national" manifestation of Russian nationalism. To replace "Moscow as the Third Rome" - the idea that after the fall of the East Roman Empire (1453) the Russian Orthodox Church became the true defender of Christianity - the Bolsheviks organized the Third International" (Comintern). And many traits of the Third Rome idea were transferred to it. The Third International, wrote Berdiaev, "is not an International, but the Russian national idea." 47

Olga Malinova points to a less far-fetched theory which could serve the same purpose: the construction of Russian history developed by G. A. Ziuganov and the Communist Party of the Russian Federation in the early 1990s. This is a theory about the Soviet epoch as an organic period in Russia's history rather than a deviation from its general course. Ziuganov's scheme is not an outright acceptance of the Soviet foundation myth, but its partial transformation, from the revolution being a war between classes to becoming more like "a clash between civilizations." 48 This is Lenin's thesis back to front. In this scheme, October, 1917, becomes a significant episode in the centuries-long antagonism between the West and Russia, when Russia once more stood forward as a counterweight against Western hegemony. In this connection, October changed its character as foundation myth from being an event "before" and "after," to

46 A.V. Filippov (ed.), Istoriia Rossii 1945-2008 gg. Kniga dlia uchitelia (Moskva: Prosveshchenie, 2008).

47 N. Berdiaev, Istoki i smysl russkogo kommunizma (Tbilisi: Tbilisi State University, 2013).

48 Malinova, Aktual'noe proshloe, 49-53; eadem, "Neudobnyi iubilei," 25-26. 
becoming, as it were, a peculiar manifestation of the Russian idea. It seemed, wrote Ziuganov,

that the Russian Revolution of 1917 could justify the hopes of the West to get rid of its main geopolitical rival, but they were unavailing. The Revolution did not destroy the Russian statehood (gosudarstvennost'). On the contrary, it renewed and strengthened it, cleaning it of its obsolete feudal-bourgeois forms. However, having thrown off the form, the Soviet regime at the same time rather quickly inherited from the historical Russia her moral ideals, as well as her experience as a great power in building a powerful state. ${ }^{49}$

No doubt, if Putin had accepted this way of approaching history, the connection between the First and the Second World Wars would have become clearer, and post-Soviet Russia could have continued to lean on the infrastructure of remembrance, inherited from the USSR, including the revolution. So why was this unacceptable for Putin, when we know that in the beginning of his reign he was more open to Zyuganov's theory (compare his inclusion of Soviet symbols in the Russian symbolic field)? The problem is that what Zyuganov's scheme gains in historical continuity is lost in a continuity of regimes. ${ }^{50}$ Obviously, Putin's remonstrance is related to the so-called color revolutions in the post-Soviet space, which has created fear that a color revolution can take place in Russia too. Ziuganov's scheme is, as Malinova underlines, less advantageous to a party in power than to a party hoping to obtain power. And the message that the revolutionary deconstruction of one state apparatus or regime can result in a state or regime that is even stronger is not a message that the Kremlin leadership today is ready to convey to the Russian people.

\section{Bibliography}

Assmann, Aleida. Der lange Schatten der Vergangenheit: Erinnerungskultur und Geschichtspolitik. München: Beck, 2006.

Berdiaev, N. Istoki i smysl russkogo kommunizma. Tbilisi: Tbilisi State University, 2013.

Buldakov, V. P., and T. G. Leont'eva, Voina, porodivshaia revoliutsiiu: Rossiia, 1914-1917 gg. Moskva: Novyi khronograf, 2015.

49 G. A. Ziuganov, "Vzgliad za gorizont," Obozrevatel' (Moscow) 18 (1994): 144, accessed May 19, 2018, http://www.observer.materik.ru/observer/N18_94/18_20.htm.

50 See Inozemtsev, "Razdvoenie soznaniia." 
Davies, R. W. Soviet History in the Yeltsin Era. London: Macmillan Press, 1997.

Enteen, George M. The Soviet Scholar-bureaucrat: M. N. Pokrovskii and the Society of Marxist Historians. University Park: The Pennsylvania State University Press, 1978.

Filippov, A. V. (ed.). Istoriia Rossii 1945-2008 gg. Kniga dlia uchitelia. Moskva: Prosveshchenie, 2008.

Fitzpatrick, Sheila. "Celebrating (or Not) the Russian Revolution," Journal of Contemporary History 52 (2017): 816-831.

Horvath, R. "Apologist or Putinist? Solzhenitsyn, the Oligarchs, and the Specter of Orange Revolution.” The Russian Review 70, no. 2 (2011): 300-318.

Inozemtsev, Vladislav. "Razdvoenie soznaniia." Nezavisimaia gazeta (Moscow), November 7, 2012.

Kangaspuro, Markku. "History Politics and the Changing Meaning of Victory Day in Contemporary Russia." In The Long Aftermath: Cultural Legacies of Europe at War, 19362016, edited by Manuel Bragan and Peter Tame, 333-343. Oxford: Berghahn Books, 2015.

Kolonitskii, B. I. "On Studying the 1917 Revolution: Autobiographical Confessions and Historiographical Predictions." Kritika: Exploration in Russian and Eurasian History 16, no. 4 (2015): 751-768.

Koposov, Nikolai. Pamiat' strogogo rezhima: Istoriia i politika v Rossii. Moscow: Novoe literaturnoe obozrenie, 2011.

Lundby Gjerde, Kristian. "The Use of History in Russia 2000-2011: The Kremlin and the Search for Consensus." East European Politics 31, no. 2 (2015): 149-169.

Malinova, Olga Iu. Aktual'noe proshloe: Simvolicheskaia politika vlastvuiushchei elity i dilemmy rossiiskoi identichnosti. Moscow: ROSSPEN, 2015.

_—_. "Neudobnyi iubilei: Itogi pereosmysleniia 'Mifa osnovaniia' SSSR v ofitsial'nom istoricheskom narrative RF." Political Science (RU) 3 (2017): 13-40.

Miliukov, Pavel N. Ocherki po istorii russkoi kultury, vol. 1. St. Petersburg: Tipografiia M. A. Aleksandrova, 1904.

Miller, A. I. "Istoricheskaia politika v Vostochnoi Evrope nachala XXI veka." In Istoricheskaia politika $v$ XXI veke, edited by A. Miller and M. Lipman, 7-32. Moscow: Novoe literaturnoe obozrenie, 2012.

"Navstrechu 100-letiiu Revoliutsii: Zveno v istoricheskoi preemstvennosti i platforma primireniia," May 20, 2015. Accessed May 26, 2018. http://www.odnako.org/blogs/navstrechu100-letiyu-revolyucii-zveno-v-istoricheskoy-preemstvennosti-epoha-gigantskih-dostizheniyi-platforma/.

Nielsen, Jens Petter. “'̊ skape mening i konsolideringens navn’: Den russiske revolusjonens hundreårsjubileum." Arbeiderhistorie (2017): 23-41.

Novoselova, Elena. "Poka Lenin na Krasnoi ploshchadi, revoliutsiia prodolzhaetsia." Rossiiskaia gazeta, November 17, 2015. Accessed January 6, 2017. https://rg.ru/2015/11/18/radzinskiy.html.

Read, Christopher. War and Revolution in Russia, 1914-1922. Basingstoke: Palgrave Macmillan, 2013. 
Rendle, Matthew, and Aaron B. Retish. "Silences and Noises: Commemorating 1917." Revolutionary Russia 30, no. 2 (2017): 151-157.

Ryan, James. "The Politics of National History: Russia's Ruling Elite and the Centenary of 1917." Revolutionary Russia 31 (2018): 1-22.

Sanborn, Joshua A. Imperial Apocalypse: The Great War and the Destruction of the Russian Empire. Oxford: Oxford University Press, 2014.

Shteppa, Konstantin F. Russian Historians and the Soviet State. New Brunswick: Rutgers University Press, 1962.

Skocpol, Theda. States and Social Revolutions: A Comparative Analysis of France, Russia and China. Cambridge: Cambridge University Press, 1979.

Smith, S. A. "The Historiography of the Russian Revolution 100 Years On." Kritika: Exploration in Russian and Eurasian History 16 (2015): 733-749.

-_- Russia in Revolution: An Empire in Crisis, 1890 to 1928. Oxford: Oxford University Press, 2017.

Sokolov, N. "Vek surka, ili Kratkaia istoriia kolovrashcheniia rossiiskikh uchebnikov istorii." Polit. $r u$, October 15, 2008. Accessed October 18, 2016. www.polit.ru/analytics/2008/10/15/ history.html.

Solzhenitsyn, A. I. Publitsistika, vol. 1. Iaroslavl: Verkhniaia Volga, 1995. Stoletnii iubilei revoliutsii 1917 goda i rossiiskaia politika pamiati: Kommemoratsii stoletiia revoliutsii v Rossii: ot pamiati $k$ politikam pamiati. November 7, 2017. Accessed May 26, 2018. http://gefter.ru/ archive/23171.

Timasheff, Nicholas. The Great Retreat: The Growth and Decline of Communism in Russia. New York: D. P. Dutton, 1946.

Tolz, Vera. "Modern Russian Memory of the Great War, 1914-1920." In The Empire and Nationalism at War, edited by E. Lohr, V. Tolz, A. Semyonov, and M. von Hagen, 257-285. Bloomington: Slavica, 2014.

"V Moskve otkryli memorial zhertvam repressii." Novaia gazeta, October 30, 2017. Accessed May 9, 2018. https://www.novayagazeta.ru/news/2017/10/30/136550-v-moskve-otkrylimemorial-zhertvam-repressiy-na-tseremoniyu-otkrytiya-steny-skorbi-priehal-putin.

Wade, R. "The Great War, Revolution and the Struggle Over Peace: Russia 1917." Revolutionary Russia 30, no. 2 (2017): 182-195.

Ziuganov, G. A. "Vzgliad za gorizont." Obozrevatel' (Moscow) 18 (1994): 144. Accessed May 19, 2018. http://www.observer.materik.ru/observer/N18_94/18_20.htm. 
